\title{
Genetic Control of $\mathrm{O}_{3}$ Sensitivity in a Cross Between Two Cultivars of Snap Bean
}

\author{
Richard A. Reinert and Gwen Eason \\ U.S. Department of Agriculture-Agricultural Research Service and Department of Plant Pathology North \\ Carolina State University, Raleigh, NC. 27695-7616
}

\begin{abstract}
AdDitional INDEX wORDS. Phaseolus vulgaris, air pollution, plant breeding
AbSTRact. Identification of genetic control of ozone $\left(\mathrm{O}_{3}\right)$ sensitivity is desirable for selection of plant cultivars which are indicators

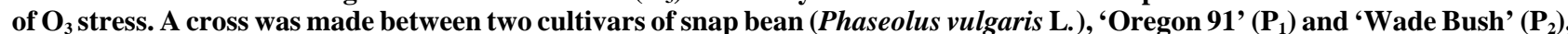
an $\mathrm{O}_{3}$-sensitive and $\mathrm{O}_{3}$-insensitive cultivar, respectively. Ten genetic populations (generations), 'Oregon 91' ( $P_{1}$ ), 'Wade Bush' $\left(P_{2}\right), F_{1}, F_{2}$, backcrosses to both parents, and all reciprocal crosses, were field planted in each of two summers and evaluated for injury to $\mathrm{O}_{3}$. Ozone responses for the reciprocal crosses were not significantly different for any generation, so injury ratings from the reciprocal crosses were combined for each generation to provide six populations $\left(\mathrm{P}_{1}, \mathrm{P}_{2}, \mathrm{~F}_{1}, \mathrm{~F}_{2}, \mathrm{BC}_{1}\right.$, and $\left.\mathrm{BC}_{2}\right)$ for analysis. When components of genetic variation were estimated from the six generations, additive genetic variance was the most important component in the total genetic variance available, although dominance variance was also a significant component. There was an inconsistency in the magnitude and the direction of the factors contributing to the dominance effects and also a large environmental component making up the phenotypic variance. Estimates of broad-sense heritability and narrow-sense heritability were $60 \%$ and $44 \%$, respectively. Results suggest that $\mathrm{O}_{3}$-sensitive and $\mathrm{O}_{3}$-insensitive selections could be screened and evaluated in an ambient $\mathrm{O}_{3}$ environment. Several generations will be necessary, however, to develop 'Bush Blue Lake' type selections that vary only in sensitivity to $\mathrm{O}_{3}$.
\end{abstract}

Ozone $\left(\mathrm{O}_{3}\right)$ is the most important phytotoxic air pollutant in the United States injuring both field- and glasshouse-grown plant species. It is also a concern in other parts of the world including southern Europe (Gimeno et al., 1995; Schenone et al., 1994). Plant stress induced by $\mathrm{O}_{3}$ results in crop losses totaling several billion dollars annually (Heck et al., 1991). Thus, the economic impact of $\mathrm{O}_{3}$ effects on crop growth and productivity continue to be significant.

Sensitivity among species and cultivars within species to $\mathrm{O}_{3}$ has been studied since $\mathrm{O}_{3}$ was identified as causing damage to tobacco (Nicotiana tabacum L.) (Heggestad and Middleton, 1959). Gableman (1970) suggested that air pollutants such as $O_{3}$ have not been normal constituents of the environment in which plants have grown over centuries. Therefore, continuous selection pressure has not been present to isolate genes for resistance. Genetic modification of plants for tolerance to air pollutants has been reviewed (Reinert et al., 1982). Studies of gene control over susceptibility and resistance in crops to $\mathrm{O}_{3}$ have been conducted for tobacco (Aycock, 1972; Haung et al., 1975; Povilaitus, 1967), soybean (Glycine max L.) (Damicone and Manning, 1987), onion (Allium cepa L.) (Engle and Gableman, 1966), sweet corn (Zea mays L. var. rugosa Bonaf.) (Cameron, 1974; 1975), white potato (Solanum tuberosum L.) (DeVos et al., 1982), petunia (Petunia $\times$ hybrida Hort. Vilm. Andr.) (Hanson et al., 1976) and snap bean (Phaseolus vulgaris L.) (Butler, et al., 1979; Guri, 1983; Hucl and Beversdorf, 1982b; Mebrahtu et al., 1990).

Snap bean is one of the most $\mathrm{O}_{3}$-sensitive crop species exhibiting visible injury and reduced yields under $\mathrm{O}_{3}$ stress (Heck et al. , 1988; Heggestad et al., 1980). There is wide variation in $\mathrm{O}_{3}$ -

Received for publication 9 Feb. 1999. Accepted for publication 20 May 1999. We thank Tommy Gray and Jeffory Barton for technical assistance in this study. This is a publication of the North Carolina Agricultural Research Service (NCARS), Raleigh, in cooperation with the USDA-ARS. Use of trade names in this publication does not imply endorsement by the NCARS or the USDA-ARS of the products named, nor criticism of similar ones not mentioned. The cost of publishing this paper was defrayed in part by the payment of page charges. Under postal regulations, this paper therefore must be hereby marked advertisement solely to indicate this fact. sensitivity among cultivars (Beckerson et al., 1979; Hucl and Beversdorf, 1982a; Meiners and Heggestad, 1979; Tonneijck, 1983) and among plant introductions of bean (Reinert et al., 1984). However, the inheritance of resistance to $\mathrm{O}_{3}$ in bean is not clear, and conflicting results may be due to different germplasms and the varying $\mathrm{O}_{3}$-exposure methods used. Studies with the Bush Blue Lake (BBL) germplasm in Oregon (Eason and Reinert, 1991) seemed to suggest that sensitivity to $\mathrm{O}_{3}$ may be carried from selection to selection in a breeding program. Therefore, we wanted to characterize inheritance to $\mathrm{O}_{3}$ using a highly $\mathrm{O}_{3}$ sensitive BBL snapbean cultivar, Oregon 91, and an $\mathrm{O}_{3}$-resistant snapbean cultivar, Wade Bush.

\section{Materials and Methods}

The bean genotypes chosen as parents were 'Oregon 91' $\left(\mathrm{P}_{1}\right)$, $\left(\mathrm{O}_{3}\right.$ sensitive $)$, a white-seeded BBL cultivar and 'Wade Bush' $\left(\mathrm{P}_{2}\right),\left(\mathrm{O}_{3}\right.$ insensitive $)$, a dark-seeded bush snap bean. Both cultivars have stable responses to ambient $\mathrm{O}_{3}$ in the field. Parents were crossed in a charoal-filtered glasshouse during 1991 and 1992 to obtain an $F_{1}$ population. A portion of seed from the $F_{1}$ population was sown in the glasshouse to obtain the $\mathrm{F}_{2}$ population. Another portion of the $\mathrm{F}_{1}$ population was backcrossed to both parents. Hypocotyl and flower colors served as markers to confirm successful hybridization and all crosses were made reciprocally. This gave 10 genetic populations (generations): the two parents ('Oregon 91' and 'Wade Bush'), the $\mathrm{F}_{1}$ ('Oregon 91' $\mathrm{x}$ 'Wade Bush' and 'Wade Bush' $X$ 'Oregon 91'), the $F_{2}$ (selfs from both $F_{1}$ populations), and the backcrosses $\left(\mathrm{P}_{1} \times \mathrm{F}_{1}, \mathrm{~F}_{1} \times \mathrm{P}_{1}, \mathrm{P}_{2} \times \mathrm{F}_{1}, \mathrm{~F}_{1} \times \mathrm{P}_{2}\right)$.

The 10 populations were hand planted in the field at the Central Crops Experiment Station, Clayton, N.C., during Summers 1992 and 1993. The field design for each year consisted of four replications of 10-plant plots. To avoid low plant numbers from poor germination or poor seedling growth, nonsegregating generations in each replication were double-seeded and thinned to the 10 plants exhibiting the best growth habit $20 \mathrm{~d}$ after seeding. Segregating generations, the $\mathrm{F}_{2}$ and backcross generations, were expected to have the greatest amount of variation in sensitivity to 
$\mathrm{O}_{3}$. These generations were not double seeded, but were planted in four, 10-plant plots per replication to provide a larger number of individual plants for evaluation. Cultural errors and soilborne disease resulted in fewer than 10 plants per row and even the loss of several whole plots by the end of the growing season.

Standard bean cultural practices for the North Carolina piedmont were followed, but timing of cultural practices varied slightly between years depending on weather conditions suitable for providing the necessary fertilization and insect control. Two insecticides, Asana (esfenvalerate) (Du Pont Agricultural Products, Wilmington, Del.) and Talstar (biphenthrin) (FMC Corp., Philadelphia, Pa.), were used as needed in this study, because they did not have any phytotoxic effects on bean and provided adequate control of insects of concern, including white fly (Aleyrodidae sp.), spider mite (Tetranychus urticae) and Western flower thrip (Frankliniella occidentalis). Plants were irrigated as needed to keep field moisture conditions high.

Hypocotyl color of each plant was recorded in the seedling stage, and as the plant matured, flower color was determined. Data from these markers were used to check segregation ratios for the crosses. Individual plant $\mathrm{O}_{3}$-injury ratings were made 42 and $52 \mathrm{~d}$ after seeding representing the full-flowering and the pod-fill stages of plant growth. Because of the large number of plants, individual leaves were not rated. Injuries of the total leaf surface were evaluated on a 0 to 10 scale. A rating of zero (0) was given if there was no injury, and a rating of 10 was assigned when all leaves were injured and/or abscised.

Injury ratings were analyzed using a least squares analysis weighted by the inverse of the number of plots (observations) per generation mean (Halward and Wynne, 1991). Mean squares were examined to determine whether or not generations differed for severity of $\mathrm{O}_{3}$ injury and whether or not these differences were consistent over the 2 years. Reciprocal crosses were tested for homogeneity of response using contrast statements. Since reciprocal crosses were not found to be heterozygous in $\mathrm{O}_{3}$ response, data from the reciprocal crosses were combined, reanalyzed with weighted least squares, and the least square means were obtained for the generation means analysis. Individual weighted least squares analyses were also conducted on three groups of generations expected to have similar within plot variances (backcrosses, $F_{1}$ and parents, $F_{2}$ ), and the residual variances were used as estimates of the variance within generations for the generation means analysis (Halward and Wynne, 1991). A jointscaling test (Cavalli, 1952) was used to test the adequacy of the three-parameter, additive-dominance model, and, if the model was adequate, to obtain the best possible estimates of those parameters (Mather and Jinks, 1977).

Rowe and Alexander (1980) modified the methods of Mather and Jinks (1977) to better estimate the standard errors of the parameter estimates, and their matrix notation was followed for this analysis. The following matrices were used in the generation means analysis: a) the diagonal matrix of the number of plots per generation, b) the diagonal matrix of the variances of the six generations, c) the vector of generation least square means, and d) the matrix of the genetic expectations of the generation means in terms of the three parameters from the additive-dominance model. These matrices were used to solve for the estimates and standard errors of the additive-dominance model parameters: $\mathrm{m}, \mathrm{d}$, and $\mathrm{h}$, where $m$ represents the midparent value, $d$ represents the sum of the differences between the homozygote and the midparent (additive effect), and $h$ represents the sum of the differences between the heterozygote and the midparent (dominance effect), respectively (Mather and Jinks, 1977). The expected means for the generations were generated as the product of the matrix of expectations and the matrix of estimates of the model parameters. The squared deviations between the observed and expected generation means were summed to obtain a chi-square value with three degrees of freedom and used to test the adequacy of the model.

Separate analyses were run for each generation with data from all replications and both years. Components of genetic variation were estimated from the six generations available using the plant to plant variances from the one-way analysis of variance and the following formulas from Mather and Jinks (1977):

$\mathrm{E}$ (environmental component $)=\left(\sigma_{\mathrm{P} 1}^{2}+\sigma_{\mathrm{P} 2}^{2}+2 \sigma_{\mathrm{F} 1}^{2}\right) / 4$

$\mathrm{D}$ (additive component $)=4 \sigma_{\mathrm{F} 2}^{2}-2\left(\sigma_{\mathrm{BC} 1}^{2}+\sigma_{\mathrm{BC} 2}^{2}\right)$

$\mathrm{H}$ (dominance component $)=4\left(\sigma_{\mathrm{BC} 1}^{2}+\sigma_{\mathrm{BC} 2}^{2}-\sigma_{\mathrm{F} 2}^{2}-\sigma_{\mathrm{E}}^{2}\right)$ and $\mathrm{F}$ (crossproduct $[\mathrm{d} \times \mathrm{h}]$ component $)=\sigma_{\mathrm{BC} 2}^{2}-\sigma_{\mathrm{BC} 1}^{2}$ where $\mathrm{P}_{1}$ is 'Oregon 91' and $\mathrm{P}_{2}$ is 'Wade Bush' and $\mathrm{BC}_{1}$ and $\mathrm{BC}_{2}$ are the backcrosses to these parents respectively. From these variance components, the dominance ratio and consistency of sign and magnitude of effects were determined.

\section{Results}

Significant differences were detected among generation mean squares for each injury evaluation. Following the first injury reading, there was a significant difference between years, among replications, and among generations. The year $\times$ generation interaction was not significant (Table 1). Following the second injury reading, there were only differences between replication and among the different generations. There were no significant differences between years or interaction between years and generations (Table 1). The mean values for each generation (Table 1) showed that with both injury scores, 'Oregon 91 ' $\left(\mathrm{P}_{1}\right)$ had significantly more injury than 'Wade Bush' $\left(\mathrm{P}_{2}\right)$. The average injury score of $F_{1}$ plants from both injury evaluations did not differ from $\mathrm{P}_{1}$, but differed from $\mathrm{P}_{2}$. The $\mathrm{F}_{2}$ generation had an average mean score following the first reading that was not different from $\mathrm{P}_{1}$, but was different from $\mathrm{P}_{2}$. However, following the second injury evaluation period, the average injury value of

Table 1. Mean square values for injury ratings and injury score means of six generations derived from a cross between an $\mathrm{O}_{3}$-senstive and $\mathrm{O}_{3}$ insensitive snap bean cultivar.

\begin{tabular}{lrcc}
\hline \hline Source & df & Injury 1 & Injury 2 \\
\hline Year & 1 & $2.414^{* *}$ & 0.331 \\
Rep (year) & 6 & $2.916^{*}$ & $23.772^{* *}$ \\
Generation & 5 & $4.677^{* *}$ & $32.103^{* *}$ \\
Year $\times$ generation & 5 & 0.347 & 0.749 \\
Error & 29 & 0.197 & 0.206 \\
& & & \\
& & Mean & Mean \\
Generation & injury score 1 & injury score 2 \\
Parent $\left(\mathrm{P}_{1}\right)$ Oregon 91 & & $1.76 \mathrm{ab}$ & $4.50 \mathrm{a}$ \\
Parent $\left(\mathrm{P}_{2}\right)$ Wade Bush & & $0.95 \mathrm{c}$ & $2.05 \mathrm{~d}$ \\
$\mathrm{~F}_{1}$ & & $2.07 \mathrm{a}$ & $4.76 \mathrm{a}$ \\
$\mathrm{F}_{2}$ & $1.75 \mathrm{ab}$ & $3.93 \mathrm{~b}$ \\
$\mathrm{P}_{1} \times \mathrm{F}_{1}$ & $2.19 \mathrm{a}$ & $4.83 \mathrm{a}$ \\
$\mathrm{P}_{2} \times \mathrm{F}_{1}$ & $1.52 \mathrm{~b}$ & $3.49 \mathrm{c}$ \\
& &
\end{tabular}

${ }^{\mathrm{z}}$ Mean separation within columns by Waller-Duncan $\mathrm{K}$ ratio $(\mathrm{K}=100)$ $t$ test.

${ }^{*}, * *$ Significant at $P=0.05$ or 0.01 , respectively. 
Table 2. Generation means and variances for $\mathrm{O}_{3}$-injury rating 2 from a cross between two snap bean cultivars, 'Oregon 91 ' and 'Wade Bush.'

\begin{tabular}{|c|c|c|c|c|c|c|c|c|c|}
\hline \multirow[b]{2}{*}{ Generation } & \multirow[b]{2}{*}{$\mathrm{n}^{\mathrm{y}}$} & \multirow[b]{2}{*}{$V^{x}$} & \multirow[b]{2}{*}{$\mathrm{Wt}=1 / \mathrm{Vx}^{\mathrm{x}}$} & \multicolumn{3}{|c|}{ Model $^{\mathrm{z}}$} & \multicolumn{2}{|c|}{ Injury } & \multirow{2}{*}{$\begin{array}{l}\text { Difference } \\
(\text { Obs-Exp) }\end{array}$} \\
\hline & & & & $\mathrm{m}$ & $\mathrm{d}$ & $\mathrm{h}$ & Observed & Expected & \\
\hline$\overline{\left.\mathrm{P}_{1} \text { (Oregon } 91\right)}$ & 7 & 0.5659 & 1.7670 & 1 & 1 & 0 & 4.496 & 4.685 & -0.1898 \\
\hline $\mathrm{P}_{2}$ (Wade Bush) & 8 & 0.5659 & 1.7670 & 1 & -1 & 0 & 2.049 & 2.045 & 0.0041 \\
\hline $\mathrm{F}_{1}^{2}$ & 16 & 0.5669 & 1.7670 & 1 & 0 & 1 & 4.761 & 4.842 & -0.0810 \\
\hline $\mathrm{F}_{2}$ & 68 & 0.7397 & 1.3519 & 1 & 0 & 0.5 & 3.928 & 4.104 & -0.1759 \\
\hline $\mathrm{P}_{1}^{2} \times \mathrm{F}_{1}$ & 68 & 0.3406 & 2.9362 & 1 & 0.5 & 0.5 & 4.828 & 4.764 & 0.0640 \\
\hline $\mathrm{P}_{2} \times \mathrm{F}_{1}$ & 64 & 0.3406 & 2.9362 & 1 & -0.5 & 0.5 & 3.486 & 3.443 & 0.0424 \\
\hline
\end{tabular}

zThe model lists the coefficients by generation for the genetic components in the additive-dominance model; $\mathrm{m}=$ the midparent; $\mathrm{d}=$ the additive component; $\mathrm{h}=$ the dominance component.

y Number of observations (10-plant plot rows) per generation over 2 years: 1 plot $\times 4$ reps $\times 2$ years for nonsegregating parental plots; 2 reciprocals $\times 1$ plot $\times 4$ reps $\times 2$ years for nonsegrating $F_{1}$ plots; 2 reciprocals $\times 4$ plots $\times 4$ reps $\times 2$ years +4 extra plots for segregating $F_{2}$ and backcross plots. One parental and four backcross $\mathrm{P}_{2} \times \mathrm{F}_{1}$ plots were lost.

${ }^{\mathrm{x}}$ Variance of the mean; $\mathrm{Wt}$ is the reciprocal of the variances of the means, and the weighted values take into consideration the differing number of observations within each generation.

${ }^{\mathrm{w}} \mathrm{Obs}-\mathrm{Exp}=$ observed minus expected.

the $\mathrm{F}_{2}$ generation was different from both $\mathrm{P}_{1}$ and $\mathrm{P}_{2}$. The backcross of the $\mathrm{F}_{1} \times \mathrm{P}_{1}$ generation was not different from $\mathrm{P}_{1}$, but was different from $\mathrm{P}_{2}$ following both injury evaluations. This meant the $\mathrm{F}_{1}$ backcross to the $\mathrm{O}_{3}$-sensitive parent was as sensitive as the sensitive parent.

Generation means and variances from the second $\mathrm{O}_{3}$ injury ratings from the 'Oregon 91' $x$ 'Wade Bush' cross were used for further analysis (Table 2). The number of observations (n) is based on number of plots (10 plants per plot). The experiment was designed to allow greater $\mathrm{n}$ values for those populations expected to have greater variation due to plant segregation $\left(\mathrm{F}_{2}\right.$ and backcross generations). The variance for each generation is given and weighted for each generation by the $\mathrm{n}$ value. The estimates presented in Table 3 were used to calculate the expected injury means for each generation given in Table 2 . The chi-square value given in Table 3 was not significant and thus, the additive dominance model was adequate for our data without additional terms to account for interactions between genes at different loci.

The variances within snap bean generations for $\mathrm{O}_{3}$ injury are presented for each family in Table 4 . The genetic expectations for these variances are also listed for each generation, along with the components, estimates, and a description of each component. These data show there is a higher level of additive than dominance genetic variance and a sizeable environmental variance component. Most of the environmental variance can be explained by the phenotypic variation of growth and development in the presence of changing environmental factors. These are probably factors affecting the general sensitivity to $\mathrm{O}_{3}$ rather than year to year changes, because variance estimates were based on plant to plant variation.

The distribution or percentage of total plant numbers at each score level within each generation are presented in Figs. 1 to 3. In the case of 'Oregon 91' (Fig. 1A), 62.3\% of the plants scored 5 or above. The backcross of the $F_{1}$ to 'Oregon 91' was more like 'Oregon 91 ', since $58.4 \%$ of the plants scored a 5 or above (Fig. $3 \mathrm{~A}$ ). In the case of 'Wade Bush', $97.3 \%$ of the plants scored a 5 or below. The backcross of the F to 'Wade Bush' was more like 'Wade Bush', since $83.6 \%$ of the plants scored a 5 or below (Fig. 3B). In the $\mathrm{F}_{1}$ (Fig. 2A), 55.5\% of the plants scored a 5 or above, which was nearly identical to 'Oregon 91 ' $(62.3 \%)$, and with the $\mathrm{F}_{2}$ population (Fig. 2B) this value was $40.8 \%$. The percentage of plants scoring injury of 4 to 6 in the $\mathrm{F}_{2}$ generation was $\approx 60 \%$ and segregation of sensitive and insensitive plants was rather evenly distributed.

\section{Discussion}

The cross of 'Oregon 91' x 'Wade Bush' was chosen because both were determinate snap bean cultivars with differences in $\mathrm{O}_{3}$

Table 3. Estimates with standard errors based on the three-parameter genetic model for $\mathrm{O}_{3}$-injury rating 2 for the cross between 'Oregon 91' and 'Wade Bush' snap beans.

\begin{tabular}{lccc}
\hline \hline $\begin{array}{l}\text { Genetic } \\
\text { parameter }\end{array}$ & Estimate & $\mathrm{SE}$ & $P>\mathrm{t}$ \\
\hline $\mathrm{m}^{\mathrm{z}}$ & 3.365 & 0.177 & 0.001 \\
$\mathrm{~d}^{\mathrm{y}}$ & 1.320 & 0.112 & 0.001 \\
$\mathrm{~h}^{\mathrm{x}}$ & 1.476 & 0.336 & 0.001
\end{tabular}

Chi-square value ${ }^{\mathrm{w}} \chi^{2}(3)=4.641 ; \mathrm{p}=0.25$.

${ }^{\mathrm{z}_{\mathrm{m}}}=$ midparent or midpoint between the two homozygous parents.

$\mathrm{y}_{\mathrm{d}}=$ additive genetic component; $\mathrm{d}$ is the sum of the differences between the homozygotes and the midparents (over all factors involved in the expression of $\mathrm{O}_{3}$ sensitivity).

${ }^{\mathrm{x}} \mathrm{h}=$ dominance genetic component; $\mathrm{h}$ is the sum of the differences between the heterozygotes and the midparents (over all factors involved in the expression of $\mathrm{O}_{3}$ sensitivity).

whe chi-square value is the sum of the squared, weighted differences between the observed and expected means for the six generations. Since the probability of obtaining a greater chi-square is nonsignificant, the additive-dominance model is considered to adequately explain the data.

Table 4. Variances within snap bean generations for $\mathrm{O}_{3}$-injury rating 2 in the cross between 'Oregon 91' and 'Wade Bush' snap beans.

\begin{tabular}{lcl}
\hline \hline Family & Variance & Expectation \\
\hline $\mathrm{P}_{1}$ & 1.96 & $\mathrm{Ew}=0.25 \mathrm{VP} 1+0.25 \mathrm{VP} 2+0.5 \mathrm{VF} 1$ \\
$\mathrm{P}_{2}$ & 0.76 & $\mathrm{Ew}$ \\
$\mathrm{F}_{1}$ & 1.82 & $\mathrm{Ew}$ \\
$\mathrm{F}_{2}$ & 4.00 & $0.5 \mathrm{D}+0.25 \mathrm{H}+\mathrm{E}$ \\
$\mathrm{BC}_{1}$ & 3.47 & $0.25 \mathrm{D}+0.25 \mathrm{H}-0.5 \mathrm{~F}+\mathrm{E}$ \\
$\mathrm{BC}_{2}$ & 2.76 & $0.25 \mathrm{D}+0.25 \mathrm{H}+0.5 \mathrm{~F}+\mathrm{E}$ \\
& & \\
Component & Estimates & \\
\hline $\mathrm{D}$ & 3.543 & Additive component \\
$\mathrm{H}$ & 2.576 & Dominance component \\
$\mathrm{F}$ & -0.710 & $\mathrm{~F}=\mathrm{S}($ dh); negative denotes dominance of \\
& & Wade (BC has smaller variance) \\
$\mathrm{Ew}$ & 1.588 & Environmental variance \\
$(\mathrm{H} / \mathrm{D}) 0.05$ & 0.853 & High level of dominance \\
$\mathrm{F} /(\mathrm{D} \times \mathrm{H}) 0.05$ & -0.235 & Inconsistency of hs in sign
\end{tabular}


sensitivity and with convenient markers (different hypocotyl and flower colors) for monitoring hybridization success. We have attempted to determine the heritability and genetic variance of $\mathrm{O}_{3}$ sensitivity for that cross. The total genetic variance for this cross was determined and subdivided into the additive genetic variance and dominance genetic variance. The additive-dominance model was found adequate without additional terms for genetic interaction.

This additive-dominance model assumes that the mean of the phenotypes, in this case visual injury due to $\mathrm{O}_{3}$, can be estimated by three parameters. These parameters are a midpoint value, $\mathrm{m}$, an additive component, $\mathrm{d}$, and a dominance component, $\mathrm{h}$ (Mather and Jinks, 1977). In this cross, these estimates were significantly different from zero, and the model adequately described the injury data for the generational means examined. Thus, no significant epistatic or gene interaction effects needed to be added to the model, and the additive and dominance genetic effects were well estimated. One of the limitations of the generation means analysis is that it is based on
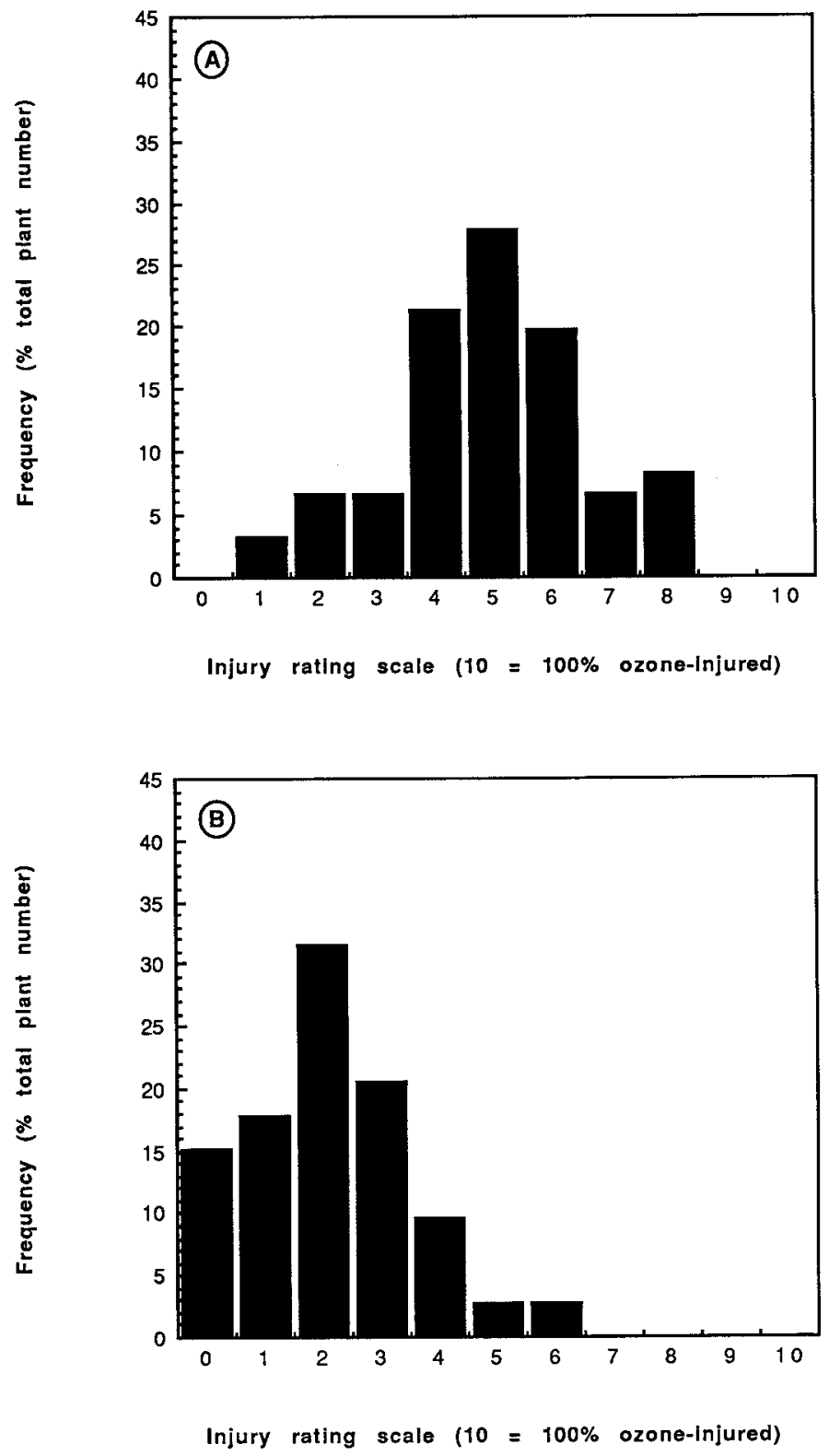

Fig. 1. Percentage of the total number of plants in each injury class; $(\mathbf{A}) \mathrm{P}_{1}$. Oregon 91', (B) $\mathrm{P}_{2}$, 'Wade Bush'. mean phenotypes, thus masking the individual effects of multiple genes if all genes do not contribute in the same direction and magnitude to the character of interest (Mather and Jinks, 1977). When individual plant data are available, variances within the generations can be used to estimate the additive (D), dominance $(H)$, crossproducts $(\mathrm{F})$, and environmental $(\mathrm{E})$ components of the genetic variation available from the cross between two cultivars. Because of the nature of second order statistics, interpretation of estimated effects is not limited by any lack of consistency in sign and magnitude as is experienced with first order statistics (Mather and Jinks, 1977). The variance components refined the information in the generation means analysis. The dominance ratio confirmed the importance of dominance in the model, whereas, the ratio of $\mathrm{F}$ / $(\mathrm{D} \times \mathrm{H})(0.05)$ indicated inconsistencies in sign and magnitude of the dominance deviations at the different loci.

Mebrahtu et al. (1990) performed a generation means analysis and found the additive-dominance model adequate, but their crosses
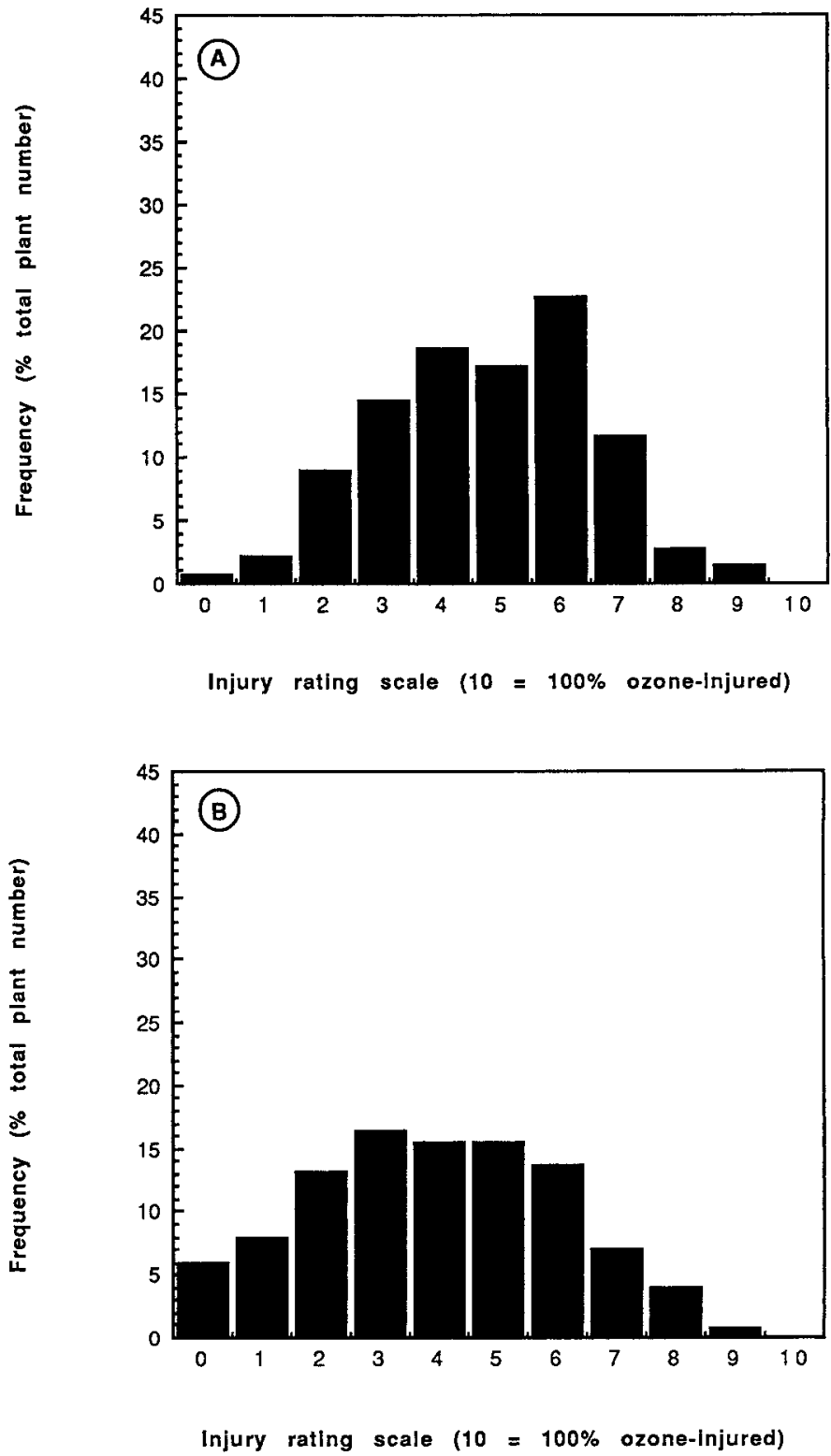

Fig. 2. Percentage of the total number of plants in each injury class; $(\mathbf{A}) \mathrm{F}_{1}$ and (B) $\mathrm{F}_{2}$ 
involved $\mathrm{BBL}_{3}$-sensitive cultivars with two $\mathrm{O}_{3}$-resistant dry bean plant introductions. They found some dominance toward insensitivity to $\mathrm{O}_{3}$ and mostly additive genetic variance. Inconsistencies between their results and ours are most likely due to the very different numbers of plants in each population. Whereas, both research efforts included sensitive, white-seeded BBL cultivars, we used a dark-seeded determinate snapbean as an $\mathrm{O}_{3}$-insensitive parent and Mebrahtu et al. (1990) used dark-seeded indeterminate dry bean plant introduction acquisitions. Other research with dry beans has also indicated dominance toward insensitivity (Guri, 1983; Hucl and Beversdorf, 1982b). Dry beans are indeterminate and slower to mature than snap beans and maturity can confound the $\mathrm{O}_{3}$ sensitivity ratings (Hucl and Beversdorf, 1982a). On the other hand, Butler et al.(1979) found dominance towards sensitivity to $\mathrm{O}_{3}$, and their work also involved dry bean cultivars. Most of these studies had inadequate plant numbers due to constraints of exposure systems used in the research.
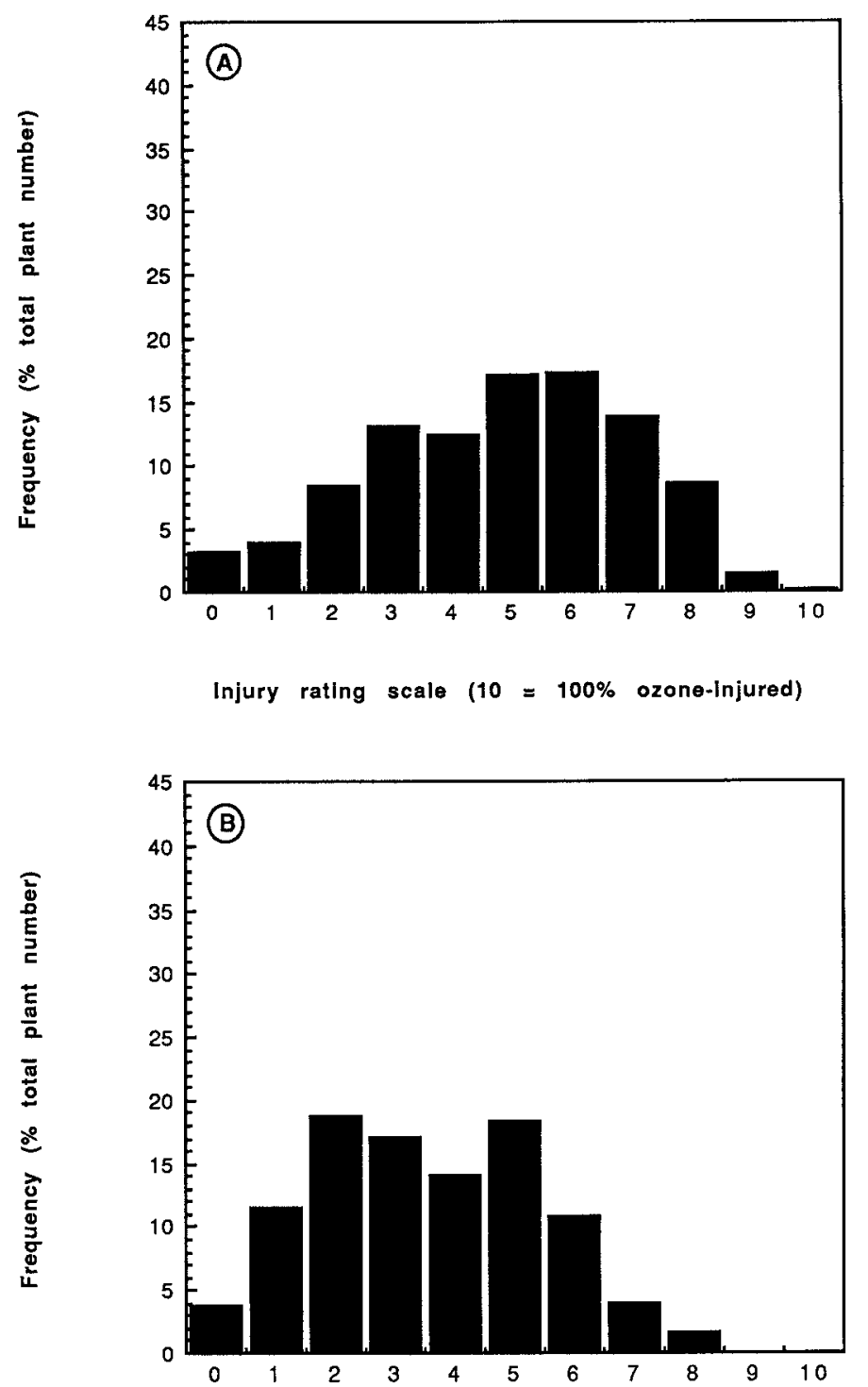

Injury rating scale $(10=100 \%$ ozone-Injured $)$

Fig. 3. Percentage of the total number of plants in each injury class; $(A) P_{1} \times F_{1}$ and (B) $\mathrm{P}_{2} \times \mathrm{F}_{1}$.
Our broad-sense heritability estimate was $60.3 \%$ and the narrowsense estimate was $44.2 \%$ for visible injury. Broad-sense heritability refers to the proportion of the total variability that is due to genetic causes, or the ratio of the genetic variance to the total variance. If broad-sense heritabilities are small, the distinction of genotype based on phenotypic differences are less clear. Since the total additive genetic variance in relation to phenotypic variance, as measured by narrow-sense heritability was moderate, selection of genotypes for high $\mathrm{O}_{3}$ sensitivity and low $\mathrm{O}_{3}$ sensitivity will require some time. Mebrahtu et al. (1990) did not give any heritability estimates in their study, and although the broad-sense heritability in the cross between 'Blue Lake Stringless' $x$ 'Black Turtle Soup' (Butler et al., 1979) was high (83\%), the $\mathrm{O}_{3}$ exposure concentration was also high $\left(1300 \mu \mathrm{L} \cdot \mathrm{L}^{-1}\right)$. The plant numbers used in the latter study were extremely low and may not have adequately represented the generations of plants involved. Broad-sense heritability estimates were also high $(66 \%$ to $88 \%)$ in the $\mathrm{F}_{2}$ generation from bean crosses made by Hucl and Beversdorf (1982b). In the $\mathrm{F}_{3}$ generation broadsense heritability estimates were low $(16 \%$ to $21 \%)$. It is difficult to compare results of these crosses with our study because of different plant populations and $\mathrm{O}_{3}$ exposure regimes.

Heritabilities in ourstudy suggest thatperhaps large environmental effects existed. The large environmental component in our study was probably due to all the factors that affect bean sensitivity to $\mathrm{O}_{3}$ including temperature, humidity, light, soil nutrition, insects, and diseases, and perhaps most importantly, changes in stomate function and uptake of $\mathrm{O}_{3}$. Stomate function has been studied using genotypes with varying sensitivities of bean and petunia (Butler et al. , 1979; Hucl and Beversdorf, 1982a; Thorne and Hanson, 1976). Engle and Gableman (1966) found that resistance to $\mathrm{O}_{3}$ was controlled by a single dominant gene thought to be responsible for loss of guard cell permeability. Guard cells of an $\mathrm{O}_{3}$-resistant onion were sensitive to $\mathrm{O}_{3}$ and lost their permeability, allowing stomatal closure, while in the susceptible plant, the guard cells were not as sensitive to $\mathrm{O}_{3}$ and allowed $\mathrm{O}_{3}$ to pass into the substomatal cavity.

In the present study, one of the reasons for understanding the inheritance patterns for the cross between 'Oregon 91' $x$ 'Wade Bush' was to determine possibilities for identifying highly $\mathrm{O}_{3}$ sensitive and $\mathrm{O}_{3}$-insensitive selections which are as phenotypically similar as possible. Our data indicated that because of the significant dominance component, selection for extremes in $\mathrm{O}_{3}$ sensitivity should follow several generations of selfing. These selections could be used in developing lines highly suitable for determining physiological and biochemical mechanisms related to variation in sensitivity to $\mathrm{O}_{3}$ in snap bean. In addition, $\mathrm{O}_{3}$-sensitive and $\mathrm{O}_{3}$ insensitive selections, if similar in yield under $\mathrm{O}_{3}$-free environments, would be expected to produce different yields related to their $\mathrm{O}_{3}$ sensitivity in ambient $\mathrm{O}_{3}$ environments. These selections could be used as seed sources of a plant indicator system in the same way as white clover (Trifolium repens) clones have been developed and used as a cloned $\mathrm{O}_{3}$ indicator and/or monitoring system (Heagle et al., 1995).

Our research differed from other studies of the inheritance of sensitivity of Phaseolus vulgaris to $\mathrm{O}_{3}$ reported in the literature. Previous studies (Butler et al., 1979; Guri, 1983; Hucl and Beversdorf, 1982b) have involved dry bean cultivars as both parents or at least one of the parents, but did not involve backcrosses of the $F_{\text {to }}$ to the parents. The study of Mebrahtu et al. (1990) involved backcrosses, but they did not examine variance components. The focus of our investigations was to develop a cross between an $\mathrm{O}_{3}$-sensitive $\mathrm{BBL}$ snap bean with known pedigree and an $\mathrm{O}_{3}$-insensitive determinate type bush snap bean with 
colored seed. We also included reciprocal crosses in our investigations. Another difference in this research from the other studies is that results of the study were based on field injury evaluations involving sufficiently high numbers and replications of individual plants to make adequate evaluations of each generation. In other studies ( Butler et al., 1979; Guri, 1983) plant numbers were few and determination of inheritance was made on injury developed from experimental exposures to $\mathrm{O}_{3}$ using varying kinds of exposure chambers.

In conclusion, it appeared possible from this study that $\mathrm{O}_{3}$ sensitive and $\mathrm{O}_{3}$-insensitive selections from this cross could be screened and evaluated in an ambient $\mathrm{O}_{3}$ environment. Results of this study showed that dominance for sensitivity to $\mathrm{O}_{3}$ was an important component in the total genetic variance available in the cross between 'Oregon 91' and 'Wade Bush' snap beans. Additive genetic variance, the useful component with a self-pollinated crop, was also a significant component of the genetic variation and a stronger contributor to the total genetic variance than dominance. This information coupled with a large environmental component making up the phenotypic variance, and an understanding of environmental impacts on $\mathrm{O}_{3}$ response in bean, highlight the challenges in breeding snap bean with insensitivity to $\mathrm{O}_{3}$. Several generations will be necessary to develop BBL-type selections which are similar and vary only in sensitivity to $\mathrm{O}_{3}$. Results of such research could be valuable tools in understanding the still elusive mechanism by which $\mathrm{O}_{3}$ damages crops.

\section{Literature Cited}

Aycock, M.W. 1972. Combining ability estimates for weather fleck in Nicotiana tabacum L. Crop Sci. 12:672-674.

Beckerson, D.W., G. Hofstra, and R. Wakasch. 1979. The relative sensitivity of 33 bean cultivars to ozone and sulfur dioxide singly or in combination in controlled exposures and to oxidants in the field. Plant Dis. Rptr. 63:478-482.

Butler, L.K. and T.W. Tibbits. 1979. Variation in ozone sensitivity and symptom expression among cultivars of Phaseolus vulgaris L. J. Amer Hort Soc. 104:208-210.

Butler, L.K., T.W. Tibbits, and F.A. Bliss. 1979. Inheritance of resistance to ozone in Phaseolus vulgaris L. J. Amer. Soc. Hort. Sci. 104:211-213.

Butler, L.K. and T.W. Tibbits. 1979. Variation in ozone sensitivity and symptom expression among cultivars of Phaseolus vulgaris L. J. Amer Hort Soc. 104:208-210.

Cameron, J.W. 1974. Patterns of inheritance of susceptibility in sweet corn to acute ozone injury under field conditions. HortScience 9:279.

Cameron, J.W. 1975. Inheritance in sweet corn for resistance to acute ozone injury. J. Amer. Hort. Soc. 100:577-579.

Cavalli,L.L. 1952. An analysis of linkage in quantitative inheritance, p. 35144. In: E.C.R. Reeve and C.H. Waddington (eds.). Quantitative inheritance. HMSO, London.

Damicone, J.P. and W.J. Manning. 1987. Foliar sensitivity of soybeans from early maturity groups to ozone and inheritance of injury response. Plant Dis. Rptr. 71:32-36.

DeVos, N.E., R.R. Hill, Jr., E.J. Pell, and R.H. Cole. 1982. Quantitative inheritance of ozone resistance in potato. Crop Sci. 22:992-995.

Eason, G. and R.A. Reinert. 1991. Responses of closely related Bush Blue Lake snap bean cultivars to increasing concentrations of ozone. J. Amer. Soc. Hort. Sci. 116:520-524.

Engle, R.L. and W.H. Gabelman. 1966. Inheritance and mechanism for resistance to ozone damage in onion, Allium cepa L. J. Amer. Hort. Soc. 9:423-430.

Gabelman, W.H. 1970. Alleviating the effects of air pollution by modifying the plant. HortScience 5:250-252.
Gimeno, B.S., J. Penuelas, J.L Porcuna, and R.A. Reinert. 1995. Biomonitoring ozone phytotoxicity in eastern Spain. Water, Air, Soil Pollut. 85:1521-1526.

Guri, A. 1983. Attempts to elucidate the genetic control of ozone sensitivity in seedlings of Phaseolus vulgaris L. Can. J. Plant Sci. 63:27-31.

Halward, T.M. and J.C. Wynne, 1991. Generation means analysis for productivity in two diverse peanut crosses. Theor. Appl. Genet. 82:784792.

Hanson, G.P., D.H. Addis, and L. Thorne. 1976. Inheritance of photochemical air pollution tolerance in petunias. Can. J. Gen. Cytol. 18:579_ 592.

Heagle, A.S., J.E. Miller, B.I. Chevone, T.W. Dreschel, W.J. Manning, P.M. McCool, C.L. Morrison, G.E. Neely, and J. Rebbeck. 1995. Response of a white clover indicator system to tropospheric ozone at eight locations in the United States. Water, Air, Soil Pollut. 85:1373-1378.

Heck, W.W., J.A. Dunning, R.A. Reinert, S.A. Prior, M. Rangappa, and P.S. Benepal. 1988. Differential responses of four bean cultivars to chronic doses of ozone. J. Amer. Soc. Hort. Sci. 113:46-51.

Heck, W.W., A.S. Heagle, J.E. Miller, and J.O. Rawlings. 1991. A national program (NCLAN) to assess the impact of ozone on agricultural resources, p. 225-254. In: R.L. Berglund, D.R. Lawson, and D.J. McKee (eds.). Tropospheric ozone and the environment. Intl. Specialty Conf., Los Angeles, Calif., 19-22 Mar. 1990. Air and Waste Mgt. Assn., Pittsburgh, $\mathrm{Pa}$.

Heggestad, H.E., A.S. Heagle, J.H. Bennett, and E.J. Koch. 1980. The effects of photochemical oxidants on the yield of snap beans. Atmos. Environ. 14:317-326.

Heggestad, H.E. and J.T. Middleton. 1959. Ozone in high concentrations as a cause of tobacco leaf injury. Science 129:371-390.

Huang, T.R., M.K. Aycock, Jr., and C.L. Mulchi. 1975. Heterosis and combining ability estimates for air pollution damage, primarily ozone, in Maryland tobacco. Crop Sci. 15:785-789.

Hucl, P. and W.D. Beversdorf. 1982a. The response of selected Phaseolus vulgaris $\mathrm{L}$. cultivars to ozone under controlled fumigation and field levels. Can. J. Plant Sci. 62:561-569.

Hucl, P. and W.D. Beversdorf. 1982b. The inheritance of ozone insensitivity in select Phaseolus vulgaris L. populations. Can. J. Plant Sci. 62:861865.

Mather, K. and J.L. Jinks. 1977. Introduction to biometrical genetics. Cornell Univ. Press, New York.

Mebrahtu, T., W. Mersie, and M. Rangappa. 1990. Generation means analysis of inheritance of insensitivity to ozone injury in two crosses of beans (Phaseolus vulgaris L.). J. Hort. Sci. 65:19-24.

Meiners, J.P. and H.H. Heggestad. 1979. Evaluation of snap bean cultivars for resistance to ambient oxidants in field plots and to ozone in chambers. Plant Dis. Rptr. 63:273-277.

Povilaitus, B. 1967. Gene effects for tolerance to weather fleck in tobacco. Can. J. Genet. Cytol. 9:327-334.

Reinert, R.A., J.A. Dunning, W.W. Heck, P.S. Benepal, and M. Rangappa. 1984. Screening of bean (Phaseolus vulgaris) for sensitivity to ozone. HortScience 19:86-88.

Reinert, R.A., H.E. Heggestad, and W.W. Heck. 1982. Plant response and genetic modification of plants for tolerance to air pollutants, p. 259-292. In: Christiansen and Lewis (eds.). Breeding for less favorable environments. Wiley, New York.

Rowe, K.E. and W.L. Alexander. 1980. Computations for estimating the genetic parameters in joint-scaling tests. Crop Sci. 20:109-110.

Schenone, G., L. Fumagalli, L. Mignanego, F. Montinaro, and G.F. Soldantin. 1994. Effects of ambient air pollution in open-top chambers on bean (Phaseolus vulgaris L.). New Phytologist 126:309-315.

Thorne, L. and G.P. Hanson. 1976. Relationship between genetically controlled ozone sensitivity and gas exchange rate on Petunia hybrida Vilm. J. Amer. Soc. Hort Sci. 101:60-63.

Tonneijck, A.E.G. 1983. Foliar injury response of 24 bean cultivars (Phaseolus vulgaris L.) to various concentrations of ozone. Neth. J. Plant Pathol. 89:79-86. 